\title{
“Doutores do mato": o entrecruzamento de histórias e memórias da pajelança, Maranhão, 1946-1988
}

\author{
"Bush doctors:" intersections between stories and \\ memoirs of pajelança, Maranhão, 1946-1988
}

\author{
Iranilson Buriti de Oliveira \\ Professor, Universidade Federal de Campina Grande. \\ orcid.org/0000-0001-8176-6670 \\ iburiti@yahoo.com.br
}

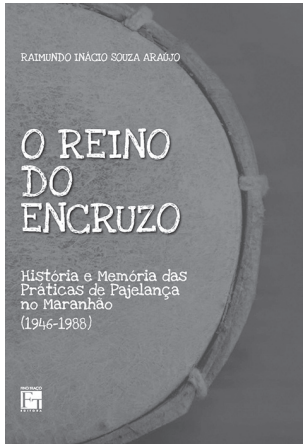

ARAÚJO, Raimundo Inácio Souza. O reino do encruzo: história e memória das práticas de pajelança no Maranhão (1946-1988). Belo Horizonte: Fino Traço. 2017. 290p.
O livro de autoria de Raimundo Inácio Souza Araújo, professor do Colégio de Aplicação da Universidade Federal do Maranhão, apresenta-nos, de uma maneira sensível e respeitosa, as práticas culturais associadas à pajelança no Maranhão, dando visibilidade às transformações ocorridas com a intensificação do êxodo rural e com a pluralização do campo religioso, principalmente com a chegada da prelazia católica e dos evangélicos de viés neopentecostal no município de Pinheiro e em outros municípios maranhenses, avessos aos entrecruzamentos e trânsitos culturais que marcavam as religiosidades locais. Com uma narrativa rica de significados, o livro é um convite à reflexão sobre (in)tolerância religiosa no contexto contemporâneo e ao ato de narrar o outro a partir da negatividade, a exemplo do catolicismo e do (neo)pentecostalismo, interpretações cristãs que viam nas práticas de pajelança crenças e costumes que deveriam ser abandonados.

A pajelança emerge nas 288 páginas do livro como uma manifestação cultural que integra o complexo religioso afro-maranhense, marcado por um regime de entrecruzamentos que dialoga com o tambor de mina, o catolicismo popular, o espiritismo e as práticas curativas. O pajé insurge textualmente como uma autoridade no plano dos cuidados terapêuticos, incluindo a realização de partos no meio rural, num período histórico marcado pela ausência de médicos na cidade e no campo, territórios pontilhados pela presença de curandeiros e seus unguentos, permeando as sensibilidades e sociabilidades do tecido rural-urbano e sua interface com os ritos lúdico-religiosos. A gramática musical está por toda parte, desde os sons dos tambores, as ladainhas, as cantigas e as doutrinas que convocam os encantados, incorporando-se inicialmente no pajé e, depois, nos demais filhos do terreiro. O estado de transe, a voz alterada e a performance desenham o corpo dos incorporados e contribuem para a construção da teatralidade da festa. 
O livro, organizado em cinco capítulos, além de apresentar o Maranhão como campo de estudo para as africanidades, discute, também, as transformações históricas ocorridas com a pajelança no período entre 1946 e 1988, as práticas terapêuticas, o cotidiano de pajés e de frequentadores dos barracões, o cruzamento de figuras como o padre, o pajé, o pastor, a benzedeira, a parteira, os santos católicos, as entidades espirituais e as cerimônias que envolvem tanto o tambor de mina quanto o encruzo, sem deixar de lado o tambor de crioula com suas sonoridades, muito marcante no terreiro Santa Bárbara, localizado no município de Presidente Sarney. A musicalidade dos terreiros do Maranhão também envolve as sonoridades do catolicismo popular e das brincadeiras folclóricas do período junino, um diálogo importante que os líderes dos barracões primam em conservar.

Os cinco capítulos do livro são relatos do fantástico, cartografados como pedaços de experiências culturais particulares do interior do Maranhão, práticas discursivas e não discursivas vivenciadas por homens e mulheres, pretos e brancos, crianças e adultos em busca de cura, de experiências místicas, de encontro com as entidades de encantaria ou simplesmente à procura de lazer e de sociabilidades. A memória oral de habitantes da zona rural de Pinheiro, bem como de outras cidades do interior do Maranhão, traz à baila um grande número de circunstâncias em que os "doutores do mato" (expressão popular pela qual também se designavam os pajés) administravam cuidados no tratamento de enfermidades físicas e espirituais.

As estratégias de sobrevivência da pajelança também são um objeto à parte. O livro mostra que, no decorrer do século XX, a pajelança passou por um processo de fusão com o tambor de mina (as licenças emitidas pelo poder público só eram concedidas para as festas relativas ao tambor de mina), em virtude da perseguição movida contra os pajés.

Os capítulos apresentam, em sequência, os "doutores do mato" e a teatralização dos atos de curar dos curadores, que atuavam na promoção da saúde por meio da preparação de garrafadas, banhos, benzimentos, da prescrição de ervas ou ainda da realização de procedimentos de cura ritual, associando os conhecimentos tradicionais acumulados à relação especial que tinham com entidades sobrenaturais. Na ausência de políticas de assistência à saúde, afirmava-se a centralidade dos curandeiros no contexto das pequenas comunidades em que residiam. Era habitual o doente visitar primeiro os pajés e, posteriormente, recorrer aos médicos. Portanto, o livro é uma importante contribuição historiográfica para a história da saúde no século XX.

Destaco que as imagens em preto e branco reproduzidas no livro aparecem apenas de forma ilustrativa, sem a devida crítica autoral, sendo que, algumas delas, não apresentam boa qualidade visual (p.48 e 49, por exemplo). Outro ponto que considero uma fragilidade da obra diz respeito às narrativas orais, pouco problematizadas pelo autor. Os relatos orais de pajés e migrantes da zona rural aparecem em diversos momentos do trabalho como "a verdade", diferentemente da crítica textual que é tecida aos documentos produzidos pela diocese de Pinheiro e por escritores locais.

Apesar de repetitivo em muitos momentos, apresentando elementos desnecessários e reiterando o que havia sido dito em capítulos anteriores, o livro de Raimundo Inácio textualiza didaticamente o ritual da pajelança e os trabalhos terapêuticos oficiados pelas entidades sobrenaturais incorporadas pelo pajé. A cura ritual que envolve a defumação 
da pessoa e a sucção de substâncias misteriosas do corpo doente, cuja atuação maléfica é sustada pela atuação do curador, é descrita com maestria pelo autor.

Finalmente, Raimundo Inácio apresenta os deslocamentos que ocorreram nesse contexto histórico. Se até 1946, na ausência de igrejas, as pessoas se reuniam na pajelança, a emergência da prelazia estabeleceu um ambiente de tensão entre práticas devocionárias locais e os novos rituais. Ocorreu, assim, a modificação dos festejos e alteração nos elementos litúrgicos no interior da Igreja católica de Pinheiro. Com a chegada dos missionários, os batuques de louvação a São Benedito e a prática do tambor de crioula, costumeiramente realizados na igreja matriz, foram transferidos para a periferia. A pajelança e o curandeirismo passaram a ser relatados como opostos ao progresso e à modernidade. No ato de narrar o outro, a Igreja contribuiu para aumentar o preconceito, sem levar em consideração que praticar a pajelança era cruzar não apenas a fronteira da condição econômica, mas também aquela que separava negros e brancos, centro e periferia. Ao finalizar a leitura do livro, uma lição é muito bem evidenciada: no reino do encruzo, é preciso se despir do preconceito!

\section{REFERÊNCIA}

ARAÚJO, Raimundo Inácio Souza.

O reino do encruzo: história e memória das

práticas de pajelança no Maranhão (1946-1988).

Belo Horizonte: Fino Traço. 2017. 